\title{
Night Mail
}

\author{
Jens Christian Grøndahl
}

$I$

Jeg ankom til Edinburgh med tog sidst på eftermiddagen. Det første jeg så, da jeg steg ud på perronen, var en ældre mand i klanternet kilt. Det var lidt som at være med $i$ en Tintinbog, hvor klædedragt og topografiske detaljer altid er omhyggeligt gengivet som træfsikre, kulturelle og geografiske markører. En mand i kilt? Vi må vist være i Skotland! Jeg havde siddet ved kupévinduet og betragtet făreflokkene på de græsklædte bakker med noget, der lignede genkendelsens glæde, skønt jeg aldrig havde været i Skotland før. Det bemærkelsesværdige ved stereotype forestillinger er, at de så ofte viser sig at svare til virkeligheden. Andre gange husker man dem i stedet for det selvoplevede, simpelthen fordi det er lettere. Var der nu også får på de bakker?

Jeg var inviteret til at besøge de danskstuderende på byens universitet. Togrejsen havde taget det meste af dagen, og jeg tilbragte den med at læse og se ud på landskaberne, der skyndte sig forbi. De var ikke så forskellige fra dem derhjemme, men da de skotske bakker kom til syne, fik jeg - i sidste øjeblik - fornemmelsen af at være på rejse.

Jeg kom til at tænke på en gammel, engelsk dokumentarfilm, Night Mail, om posttoget, der i løbet af en nat tilbagelægger strækningen fra London til Edinburgh. Det var de samme nøgne bakker, der dukkede op i filmens grå daggry, fortegnet af negativridserne der slingrede som en sort regn i blæsevejr. Jeg huskede det gammeldags lokomotiv omgivet af svulmende dampskyer, filmet nedefra i dramatiske vinkler, nærbillederne af postsække der kastes af toget og lokomotivførerens årvågne ansigt i det svage skær fra førerhusets kontrollamper, mens han kører gennem det sovende land.
Det virkede nostalgisk, filminstruktørens blik for poesien i det modernes anonyme nøgternhed, selv om det ironisk nok var fremtiden, lokomotivførerens blik og kameraets linse dengang rettedes mod. Et mandskor messede på lydsiden et digt af W.H. Auden, hvoraf jeg husker enkelte strofer: „Letters for the rich, letters for the poor,/The shop at the corner, the girl next door ...//... In the farm she passes no one wakes,/But a jug in a bedroom gently shakes ..."

I nogle dage havde jeg ikke set en avis og heller ikke gjort noget forsøg på at få fat i en. Rejsen bliver ofte et frikvarter fra den permanente ophobning af nyheder fra den store verden, som man er rejst ud i. Når jeg rejser, bliver jeg endnu mere nærsynet, end jeg er i forvejen. Jeg dvæler ved detaljernes betydningsløse, men karakteristiske små forskelle, hvad enten det er vinduernes og brolægningens udformning eller ansigternes vage anderledeshed. Der er altid et eller andet at se på i sprækkerne mellem forventningens eksotiske sætstykker.

Om aftenen blev jeg inviteret ud at spise, og da man spurgte, hvor gammel jeg var, kom jeg i tanke om, at det var min tredive års fødselsdag. Jeg havde næsten glemt det, måske fordi jeg havde tilbragt det meste af dagen alene, vegeterende $i$ rejsens drømmelignende flygtighed. Men jeg blev alligevel fejret til sidst, og jeg var ret fuld, da jeg satte mig tungt på hotelsengen, alene igen.

Det var den 9. november 1989. Hotelværelset var, som hotelværelser er overalt. Jeg kunne have befundet mig hvor som helst i verden. Sløvt zappede jeg frem og tilbage mellem tv-kanalerne, indtil jeg besluttede mig for CNN. Til at begynde med sagde de mig ikke noget, de rystede, grelt oplyste billeder af en menneskemasse ved foden af en mur bemalet 
med graffiti. Nogle mænd var klatret op på muren og gik løs på den med hakker og koben, så store klumper af beton trimlede ned. Langsomt, meget langsomt, dæmrede det for min bedøvede bevidsthed, hvad det var for en mur. Nå, tænkte jeg, nu river de sgu' Muren ned ...

På en diffus og passiv måde forstod jeg, at det var noget betydningsfuldt, jeg var vidne il på tv-skærmen. Alligevel nåede begivenheden mig kun som en svag rystelse $i$ det anonyme hotelværelse, vibrerende diskret som Audens kande i soveværelset på bondegården, mens historiens tog dundrede forbi $\mathrm{i}$ det fjerne. Jeg slukkede fjernsynet, lagde mig bagover og faldt $i$ en dyb, drømmeløs søvn.

Jeg var ikke kun så adspredt, fordi jeg var så fuld. Den holdt sig, min adspredthed, længe efter at jeg var blevet ædru, som en uforklarlig modvilje eller træghed over for den almindelige jubel i medierne. Efterhånden gik det op for mig, at medierne ikke blot fejrede østeuropæernes frigørelse fra det kommunistiske åg. Feststemningen skyldtes i lige så høj grad, at Europa for første gang $i$ mange år var scene for en vaskeægte historisk begivenhed.

Pudsigt nok fik vi straks efter besked om, at historien var forbi, men i Vesteuropa havde vi længe følt os forladt af historien. Det havde de måske også i Østeuropa. Da Krzysztof Kieslowski blev spurgt, hvad han mente om Murens Fald, svarede han lakonisk, at folk stadig skulle stå i kø ved busstoppestedet om morgenen, og at de stadig ville dø af kræft.

Tiden er ikke selv historie, og for en tid troede vi virkelig, at historiens lange skygger ikke længere kunne nå os. Indtil krigen i det, der kom til at hedde eks-Jugoslavien, belærte os om noget andet. Vi taler om Jugoslavien, som man taler om en, man engang var gift med. Historien er ikke forbi, men vi er blevet skilt fra den og fra de navne, vi gav den. Den har været os utro, den har forladt os for at gå sine egne veje, og vi skylder ikke længere hinanden noget. Men vi er bestyrtede over, at den stadig har så meget grusomhed i sig, sådan som man kan være foruroliget ved tanken om sin ,eks-“, når man hører, hvordan han eller hun gebærder sig i sit nye liv. Pludselig virker vedkommende så forfærdelig fremmed og så fremmedgørende forfærdelig.

Historien bevæger sig ikke længere i nogen bestemt retning. Ligesom tiden selv, det levede livs tid, snor den sig i spiraler og ellipser, spaltet i næsten lige så mange retninger, som der er mennesker. Kieslowskis kyniske svar var ikke bare en konstatering af, at privatlivet fylder mest $i$ ethvert menneskes liv. Det var også en påmindelse om livsvilkår, der virker anonyme fordi de er så almene, og omvendt.

Han talte om vilkår, som hverken vil blive ændret af historien, forbedringer i den offentlige transport eller lægevidenskabens fremskridt. De er både tragiske og trivielle, de omfatter såvel døden som den mindre patetiske omstændighed, at tilværelsen hovedsagelig er gjort af gentagelser og kun sjældent af store, betydningsfulde øjeblikke, hvor man deler skæbne med andre.

Flere år senere læste jeg noget, der forklarede og undskyldte min træghed, da Muren var så venlig at falde på min tredive års fødselsdag $i$ et af de hændelige sammentræf, som især forfattere har en hang til at få alt for meget ud af.

I et essay fortæller Peter Handke, at han blev ringet op af en ven kort efter den 9. november 1989 . Skulle han ikke med hen og se, hvad der skete? Det måtte da være lige noget for en forfatter, sådan at være øjenvidne til Historien selv. Handke undslog sig, han kom med nogle vage søforklaringer, han havde arbejde, der skulle gøres o.s.v. Skønt han boede i Berlin, fik han aldrig besigtiget folkemængdens nedrivningsarbejde, den skinbarlige forbrødrings muntre og tilmed sanktionerede hærværk. I stedet tog han til Nordspanien for at rejse rundt med bus mellem de ensomme provinsbyer og sidde på fodkolde pensionater med papir og blyant, bøjet over et erindringsessay om jukeboxens historie. Jeg forstod ham lige med det samme, med et stille, frimureragtigt smil.

Thomas Boberg taler $i$ et digt om, hvordan han „... afsøger det mest meningsløse for betydning/og det mest betydningsfulde for meningsløshed ..." Hvis noget på forhånd er alt for belagt med sprog 
og billeder, kan man ikke komme til. Ligesom det kan være svært at få øje på Skotland for kilte og får. Når alle er enige om, at det ene eller det andet er betydningsfuldt, provokeres man tværtimod til at forskyde perspektivet og vende optikken mod det banale og tilsyneladende ligegyldige.

De dårligste og kedeligste bøger er ofte dem, der tegner forsikring hos læseren ved i deres oplæg at skilte med vægtige og seriøse temaer. Hvorimod mange klassikere handler om noget upåagtet, inferiørt og trivielt. Når Emma Bovarys kedsomhed og ørkesløse længsel virker så fængslende, er det ikke på grund af hende selv, men takket være Flauberts blik på hendes provinstilværelse og det sprog, han lader hende komme til syne i. Stilen. Det er underfundigt nok den, der i højere grad end så meget andet gør stakkels Emma så nærværende, jeg havde nær sagt virkelig.

Men hvorfor blev min samvittighed aflastet af Peter Handkes anekdote om dengang han pjækkede fra Historien? Hvorfor blev genkendelsens glæde fulgt af et lettelsens suk? Hvad skyldes den, min samvittighedsbetonede tilskyndelse til at „engagere mig"?

Citationstegnene trænger sig på, for engagementet er jo i sig selv et historisk citat, en retorisk belastet skabelon. Det lader til, at jeg er fanget mellem en tilskyndelse, som er alt for belagt med foruddannet betydning, og en træghed der alt for spontant byder sig til med sin intime forfatterfortrolighed: den æstetiske, nærsynede og hypersensible omsorg for betydningen i „det mest meningsløse.“

Den engagerede intellektuelle - det lyder som en figur fra en gammel, sort-hvid film. Det kunne være lokomotivføreren i Night Mail, svagt belyst nedefra mens han står i sit førerhus og skuer ud i mørket med et vagtsomt blik, modernitetens budbringer der styrer gennem natten med budskaber til rig og fattig, til butikken rundt om hjørnet og til pigen inde ved siden af. En fane af hvid damp skummer hen langs vognstammens glinsende tage $i$ månelyset, sporskifter falder $i$ hak, drivstangen hamrer frenetisk under lokomotivets sorte krop, og langt borte $i$ et soveværelse klirrer en mælkekande, mens bonde- manden vender sig tungt i søvne og trykker sig ind mod sine kones varme krop. Men vi er nogle, der må være vågne, når verden sover! Nogen må sørge for, at fremskridtet når frem, før natten er omme. En bedre verden venter, i morgen, for enden af sporet...

Opfindelsen af den intellektuelle knytter sig til opfindelsen af Historien selv, modernitetens verdslige messianisme, der viste sig at være svanger med så mange forbrydelser begået for Menneskets skyld. Dette monster uden ansigt, uden navn og adresse. Før oplysningsfilosofferne var der bare tale om tidens gang, feudalismens evige Karma, kasternes og krigenes livs- og dødshjul, der kværnede tungt om sin egen akse. Man frigjorde sig fra Gud og blev Historiens slaver.

Engang havde Gud ladet sig føde som menneske for vore synders skyld. Nu lod mennesker sig genføde som straffende guder for hinanden. Fremskridtets tog viste sig at have endestation i en fangelejr, og dampen fra det udasede lokomotiv blandede sig med røgen fra krematorieovnene. Auschwitz og Gulag er i den forbindelse blot forskellige navne for det samme sted. Noget var gået galt undervejs, nogen havde pillet ved sporskiftet.

Hvis man endelig vil tale om Historiens afslutning, må man spørge sig selv, om den ikke sluttede allerede for halvtreds år siden, da det stod klart, at det nittende århundrede havde brugt halvdelen af det tyvende på sit selvmord. Efter jubelen over $\mathrm{Mu}-$ rens Fald meldte bitterheden sig hos de ældre og midaldrende østeuropæere, der måtte se i øjnene, at de havde spildt deres liv $i$ en blindgyde, mens verden fortsatte, vestpå.

Der var heller ikke for deres vedkommende tale om Historiens afslutning, men om en tilbagevenden, ikke til den moderne færd mod højere mål, men til det postmoderne liv, der fortsatte efter nultimen $i$ I945, på bedste beskub og blottet for illusioner.

Og de intellektuelle? De havde arvet den kønne side af Oplysningsfilosofien, den universelle humanisme, overbevisningen om den enkeltes værdighed og frihed. Men udfordringen for de intellektuelle er efter I989 den samme som efter 1945: at udrede såvel arv 
som gæld og lokalisere den glidende og forræderiske overgang mellem humanismen og dens totalitære modsætning, hvor mennesker ophørte med at være Historiens aktører for $\mathrm{i}$ stedet at blive genstande for historisk forarbejdning.

De har svært ved at finde deres ben, de intellektuelle. Da dragen først var død, blev de alle undersøgt for skæl. Hvem havde sagt hvad om Pol Pot? Den liberale inkvisitions moralske arkæologer fandt gulnede citater frem, og vel var de eksotiske. Men hvad er selvransagelse værd, hvis den ikke kommer af sig selv, animeret af samvittighedens roterende og svedige søvnløshed?

Samvittigheden, der var den igen. Den er næsten altid dårlig. Så meget desto mere misundelsesværdige kom de til at fremstå, de østeuropæiske dissidenter, da de kom ud af fængslerne, hvor de havde siddet som hele nationers deponerede og vel forvarede samvittighed. De havde kendt deres besøgelsestid, de havde med ærefuld nødtvungenhed forladt deres studerekamre til tiden for at sige fra på vegne af et splittet, kujoneret og forrået civilsamfund.

De kunne endda tale om individet og humanismens øvrige klenodier med en ærlig patos, der for længst var blevet os fremmed $\mathrm{i}$ det røgede og spegede Vesten. Mild som en franciskaner skiftede Vaclav Havel sin sweater ud med en dobbeltradet habit og forlod sin forfatterhybel for at beklæde præsidentembedet på det høje, hvide slot. Han havde heller ikke mere at skrive om, men han blev fortsat agtet som sit folks samvittighed.

Kan man være det? Nej, sagde Günther Grass i en tale holdt $\mathrm{i}$ forbindelse med hans halvfjerdsårs fødselsdag. Der er noget galt med et samfund, hvor samvittigheden ikke er individuel, hvor en enkelt person skal inkarnere forskellen på ret og vrang for de andre. I et demokrati har voksne mennesker ikke brug for lærere. Men har demokratiet overhovedet brug for de intellektuelle? Og hvad er en intellektuel, der giver afkald på selvforståelsen som lærer?

Det er vel blandt andet en, der stiller den slags spørgsmål. Den rastløse, hjemløse samvittigheds mumlende, enfoldige spørgsmål.
Hvorfor enfoldige? Fordi spørgsmål, som der ikke findes endelige svar på, som regel er barnlige spørgsmål. Spørge-Jørgen blev muligvis intellektuel, jeg tror han havde det i sig, men Jørgen fik smæk og Jørgen blev lagt $i$ seng. Som voksen blev han både håndsky og natteravn, ensom blandt mennesker, ofte at finde ved en bardisk efter midnat.

Forresten er jeg slet ikke sikker på, at han blev voksen. Engagementets modstand mod glemsel og tilpasning er også en modstand mod at træde ind i de voksnes rækker, hvor man så let bliver væk for sig selv mellem alle de ben, der hovedløst bare går og går.

Det må indrømmes: der er noget ungdommeligt umodent, af og til ligefrem halstarrigt ved denne fremturen, disse evindelige tirader $i$ avisernes spalter, som om verden lod sig formane, som om den ikke var uforbederligt kynisk, uimodtagelig for intellektuelle besværgelser.

Tidligere kunne den intellektuelle påberåbe sig fremskridtet, det nye og meget bedre samfund, der ventede rundt om hjørnet, til næste år. $\mathrm{Nu}$ må han nøjes med at påkalde sig en vag forestilling om anstændighed. Men det er og bliver mere voksent, mere sexet at være skamløs. Når den intellektuelle holder op med at lyde som et barn, er det fordi han er begyndt at lyde som en gammel tante.

Man forstår forfatternes udbredte tavshed, når de ikke lige bliver interviewet om deres seneste værks uudgrundeligheder. Det er også forståeligt, at gamle venstreintellektuelle tager forskud på deres otium i en kulinarisk nynnende eller livstræt gnækkende stoicisme, med hovedet på skrå og lommerne fulde af gode grunde til at lade hænderne blive dernede. For hvad skal det nytte? Vi skal jo alle dø før eller siden. Og sådan slukkes nogle af de lyseste hoveder før tiden.

Engagementets tilskyndelse opstod for mit private vedkommende af en tidlig og ubehagelig fornemmelse. Man risikerer at blive taget til indtægt for det, man ikke siger fra overfor. Man bliver farvet af det, hvis man ikke bekender kulør, fordi tavsheden også er en stiltiende accept. Hvem hører en stum protest midt i den larmende konsensus? 
Det er ikke bare et spørgsmål om at vise, hvem man er. Det er en foruroligende mistanke om, at man slet ikke er nogen, før man viser det. Hvem er du egentlig og med hvilken ret? Det handler ikke om retfærdiggørelse, snarere om en følelse af at man ikke kan yde sig selv retfærdighed uden at møde udfordringen fra den anden, de andre, alt det andet uden for blodtrykkets og selvspejlingernes lukkede kredsløb.

Og så var der alligevel altid den modsatte tilbøjelighed: det meditative, vegeterende og selvforglemmende bliks udvekslinger med den synlige verdens meningsløse former. Den glanende distraktions lille Zen, der fik Peter Handke til at fortabe sig i Galicien $i$ stedet for at tage en U-Bahn til Brandenburger Tor. Ethvert barn véd, hvad jeg taler om, enhver forfatter véd det, tror jeg. Jeg elsker den betegnelse, som de japanske mestre gav deres træsnit med banale motiver fra hverdagslivet $i$ bordellerne og landskabet udenom, tålmodige og samvittighedsfulde i deres rigdom på detaljer, men vilkårligt beskårede som fotografiske snapshots: „billeder fra den flydende verden“.

De glemte aldrig, at hvert øjeblik bare er en krusning, en flygtig refleks på tidens ustandselige strøm, et aspekt af foranderligheden, forgængeligheden, altings forvandling og bestandige opståen og hendøen. Ustadigheden var deres modus, og de drømte ikke om et bestandigt og sammenhængende ,jeg“, Vestens evindeligt korsfæstede og genopstandne Jeg, europæernes hidsige, tvivlrådige, oprørske, fortvivlet og fortvivlende moderne Jegjegjeg.

De var på én gang dybere og mere letsindige, de japanske billedskærere - jeg tøver med at kalde dem kunstnere, noget så hidsigt og indbildsk. Deres livssyn var melankolsk, ikke tragisk. De skulle heller ingen steder hen, fordi de vidste, at vi under alle omstændigheder går mod intetheden. Men det forhindrede dem ikke i at skære billeder, tværtimod.

\section{II}

Form er en måde at udelukke noget på for at inddrage og fokusere noget andet. Somme tider i form af en sandhed, man når frem til på bekostning af så og så mange fortielser, andre gange blot som den simple betingelse for at kunne stille skarpt.

Det kræver distance. Fortællingen begynder med en indrømmelse af, at det, der skal fortælles, er noget adskilt fra sproget, som man nærmer sig med ordene uden at forveksle ord med erfaring, tekst med liv. Man skriver altid et sted - et andet sted fra. Det er et senere sted, et eftersted, og det er ikke i hovedet, men til syvende og sidst på papiret og undervejs fra hoved til papir. I den forstand er realisme vel den største abstraktion af alle. Jeg kommer igen til at tænke på de gamle japanere, der snittede deres øjebliksbilleder af flygtigheden i noget så modstræbende og møjsommeligt som træ.

Men synspunkterne er forskellige, alt efter om jeg skriver en roman eller et essay. Når jeg skriver et essay, er det lidt som at skrive dagbog. Synspunktet flytter sig undervejs, dag for dag, time for time, og tekstens lange linie er vejen ad hvilken: en sti trådt gennem vildnisset, hvor betydning og betydningsløshed er filtret sammen.

Jeg véd ikke på forhånd, hvilke områder jeg kommer til at gennemrejse, hvor jeg ender, eller hvilke provisoriske pointer jeg når frem til. Hvorfor? Fordi det er mig - tekstens ,,jeg“, og fordi teksten er den måde, hvorpå jeg i nogle timer hver dag tilbringer mit liv, indtil essayet lukker sig bag mig. Der sker en udvikling med mig, når jeg skriver, fordi tiden går imens.

Det gør der også, når jeg skriver en roman, men fortællingen er snarere et tilbageblik på udviklingen, et forsøg på at trænge ind $\mathrm{i}$ dens gåde gennem personerne og deres hemmeligheder. Personerne kan ikke være mig, fordi det er mig, der skriver dem. Alligevel ender de som retrospektive udstrækninger af min person og min historie, efterhånden som det bliver klart, at den, der skriver, ikke helt er den samme før.

Det er noget andet med essays. De skrives i udviklingens nutid. De kan angribe et hvilket som helst stof alt efter mine forudsætninger og aktuelle fascinationer, idiosynkrasier eller bekymringer. Til forskel fra romanen. For mig er det ihvertfald ikke hvad som helst, der kan blive stof til en roman. Det må stå i forbindelse med mine erfaringer, min histo- 
rie, som ikke er mere enestående, end at den ligner min generations historie.

Man skriver, hvad man kan, ikke hvad man vil. De gamle formers udtryksmuligheder virker stadig ubegrænsede, men erfaringerne er det ikke, og erfaringer er det stof, som fiktion er gjort af. For min generations vedkommende er det en erfaring med historieløsheden. Det personlige livs intimitet og ensomhed, dets afskårethed fra samfundets fælles historie.

Octavio Paz mener, at ungdomsoprøret var en reprise på surrealisternes kamp for at frigøre underbevidstheden, drifterne og fantasien fra socialiseringens konformitet. På den samme måde kan man måske se marxismen i halvfjerdserne som en gentagelse af mellemkrigstidens politiske engagement, uden fascismen som formildende omstændighed og undskyldning for sovjetiseringen af så store dele af tredivernes progressive åndsliv.

Hvorfor måtte man absolut måtte blive marxist for at kunne få øje på USAs forbrydelser i Vietnam? Hvorfor var USAs imperialisme værre end Sovjetunionens?

Den kolde krigs politiske skizofreni og venstrefløjens moralske dobbeltbogholderi er selvfølgelig nemmere at få øje på $\mathrm{i}$ dag, men det er til gengæld også blevet synligt, at socialismen allerede $i$ tresserne og begyndelsen af halvfjerdserne havde mistet sit væsentligste aktiv: Historien og dens retning. Visheden om at være på vej et sted hen, og om at det er et bedre sted end her, hvor vi er. Utopiens billeder var blevet tyndere og mere diffuse, men ikke mindre forræderiske. Che Guevara var alligevel ikke revolutionens Jimi Hendrix. Stammheim blev alligevel ikke det gode håbs Golgatha, men det sidste rangerspor for Historiens allersidste og komplet udrangerede lokomotivførere.

Hvis man var barn i tresserne og ung i halvfjerdserne, er man afkom af en mærkelig udvikling. På den ene side blev stadig større dele af tilværelsen inddæmmet af velfærdsstaten, på den anden side foregik der en tiltagende privatisering af livet. Alle fik centralvarme og sociale rettigheder, men det blev altsammen så inderligt bag hækkene i parcelhus- kvarterernes tæt-lav-labyrint. Det var livsvilkårenes gennemsocialiserede småborgerliggørelse snarere end de røde halvfjerdseres had til al skønhed, der gjorde den unge litteratur $i$ firserne så vertikal og sort i sin besathed af kønnet og kroppen, det fatale og strengt eksistentielle. Ikke et ord om radiatorer!

I min generation er engagementet blevet hjemløst, for så vidt som det kunne være et engagement i samfundet, det politiske, et intellektuelt mellemværende med magten. Måske fordi magten i velfærdsdemokratiet er blevet fjern og diffus, ansigtsløs og umærkelig. Måske fordi sproget, det litterære sprog, ikke magter at overskride den personlige livsverdens grænser. Men det er alligevel tankevækkende, at fraværet af en ydre, undertrykkende magt efterlader os med denne afinagtsfølelse. Fornemmelsen af at der ikke rigtig er nogen, der har noget at sige om ,det her samfund“ eller resten af kloden. Verden bliver bare fjernere, desto mere den trænger sig på i skærmenes forvirrende montage af billeder alle vegne fra. Billeder fra den flydende verden.

Romanen byder sig ikke uden videre til som den form, hvori blikket kunne løfte sig fra den eksistentielle sfære til den politiske. Romanen er som sagt bundet til erfaringen, og det samme er selvforståelsen som romanforfatter. Det er anderledes med essayet, der synes at opstå i overgangen, i døråbningen, undervejs mellem inde og ude.

Essayet er ikke på samme måde betinget af erfaringen, for det bliver til som den skrivendes erfaring, mens der skrives. Det er som altid en erfaring med verden i sproget, men også en erfaring med at rette sproget mod verden. Essayet kommunikerer direkte uden fiktive personer som mellemled, og derfor rummer det en anden frihed og en anden forpligtelse end romanen.

I februar 1997 var jeg i Beograd for at skrive en serie avisartikler om studenternes demonstrationer mod Milosevic. For første gang i mit liv oplevede jeg den eufori, der overvælder en, når man er omgivet af 30 , 50 eller 60 tusinde mennesker, der har sat sig i bevægelse gennem gaderne: overskridelsen af det urbane livs kedsommelige normalitet, som i dette tilfælde også var en overskridelse af frygten, et 
kollektivt mod, en følelse af at være usårlige, så længe man var sammen, og en smittende, fælles glæde. Jeg må tilstå, at jeg lod mig overvælde.

I nogle dage troede jeg virkelig, at jeg sammen med studenterne i Beograd var på vej et sted hen, hver med vores plasticfløjte $i$ munden. Lyden af 60.00o trillefløjter - dét måtte da være et afgangssignal, der kunne fả Historiens lokomotiv i gang påny.

Senere fandt jeg ud af, at vi ikke havde gået i den samme retning allesammen, dér i vinterkulden mellem Beograds trøstesløse betonkarreer, selv om det umiddelbart så sådan ud. Var det alligevel for paradoksalt og naivt at forestille sig et menneskehav i bevægelse for at forsvare individets værdighed mod den nationale chauvinisme?

Kun halvdelen, måske færre, var gået på gaden for de demokratiske værdier, der $i$ et vestligt civilsamfund forekommer så indlysende. Alt for mange demonstrerede ikke mod Milosevic, fordi han havde startet krigen, men fordi han havde tabt den. For dem var han ikke en nationalistisk opvigler, men endnu en kommunistisk tyran. Det er en del af forklaringen på, hvorfor studenterbevægelsen i løbet af nogle måneder faldt fra hinanden.

Oppositionen var for en stor dels vedkommende kompromitteret af den samme nationalisme, som Milosevic havde manipuleret med for at legitimere sin magtpolitik, og de mere eller mindre anløbne oppositionspartier kom snart til at kontrollere, hvad der var startet som et spontant oprør. Allerede under mit ophold i Beograd blev jeg overrasket, når jeg talte med ganske unge mennesker og mærkede, hvordan slagterierne under Anden Verdenskrig tilsyneladende stod tydeligere for dem end de nedslagtninger, der for ganske nylig havde fundet sted, og jeg greb mig selv i at ønske mindre erindring, mere glemsel for Balkan.

En aften besøgte jeg et lille teater, der samtidig fungerede som intellektuelt åndehul og bar det lovende navn Centre for Cultural Decontamination. På væggen i den forfaldne garage, der fungerede som møderum og kantine, hang et kort over Sarajevo. Rummet blev opvarmet af en gammel, rusten jernovn. Instruktøren, som jeg talte med, var på min al- der, og hun sagde noget, som fik det til at gibbe så meget desto mere i mig på grund af vores generationsfællesskab. Hun sagde, at kunstnere og intellektuelle har et moralsk ansvar for, hvordan deres værker og andre ytringer indvirker på offentligheden.

Jeg undertrykte min instinktive irritation. Skulle vi nu igen til at være opbyggelige? Tænde et lille lys i mørket? Bringe bud om håb og forløsning til menneskene, som det er så synd for? Desværre fik jeg ikke lejlighed til at konstatere, om hun var talentfuld eller ej, instruktøren jeg mødte i centeret for kulturel afgiftning. Lød det forresten ikke lovlig pædagogisk? Anede man ikke en undertone af moralsk hygiejne? Etisk udrensning i stedet for etnisk?

Under alle omstændigheder var det ikke svært at forstå, hvorfor hun talte som hun gjorde. I modsætning til de andre østeuropæiske lande havde det kommunistiske Jugoslavien ikke fảet modstand fra et demokratisk dissidentmiljø. Jugoslaviens dissidenter var for de flestes vedkommende ikke demokrater men nationalister. Blodfællesskabet, ikke civilsamfundet, var deres alternativ til kommunismens eksperiment med social ingeniørkunst.

Det havde sin historiske forklaring. Tito gennemførte aldrig et retsopgør mod dem, der havde begået krigsforbrydelser under Anden Verdenskrig, hvad enten de var ustasjaer eller tjetnikker. Hvordan skulle han kunne det uden at tillade uafhængige domstole? Den kollektive skyld kom på begge sider til at oversvømme det individuelle ansvar. Ufrivilligt kom han til at nære og hærde den etniske identitetsfølelse, som han ellers undertrykte så resolut. Videnskabsmænd, universitetsprofessorer og forfattere viste sig som villige forbundsfæller for Milosevic, da der igen skulle pustes liv i det etniske had. De var ikke europæiske intellektuelle, viste det sig, men skjalde for den serbiske stamme.

Jeg forstod instruktørens moralske imperativ. Var det ikke netop forskellen, hun udpegede for mig, måske uden helt at være klar over det, forskellen mellem øst og vest, mellem postkommunisme og postmodernitet? Sådan beroligede jeg mig selv, da jeg var kommet hjem. Selvfølgelig måtte der være forskel på, om man skrev i Løgnens eller Ligegyldighedens 
rige. Selvfølgelig ... Men forskellen var ikke stor nok til at bortvejre det påtrængende, ja rent ud sagt amnassende $i$ hendes krav om kunstnerisk og intellektuel ansvarlighed.

Det er noget andet at skrive i et autoritært samfund, der kun holdes sammen med vold og løgne, end det er at skrive $i$ et usammenhængende mediedemokrati, hvor den ene sandhed opløser den anden $i$ en uendelig spiral af relativisme. I et diktatur er sproget monopoliseret og forvrænget i en grad, så civilsamfundet forstummer, ikke kun af frygt, men også fordi det er blevet sprogløst. I mediekulturens plaprende polyfoni bliver sproget derimod så letflydende og vægtløst, at det ikke længe kan udtrykke noget personligt erfaret. Selv erfaringen reducercs til en retorisk attitude, en karnevalsmaske der kan udskiftes med en hvilken som helst anden.

De to situationer er tilsyneladende modsatte, men alligevel er der en sammenhæng. I begge tilfælde er det at skrive ensbetydende med at forsvare ordene selv, hvad enten det er imod løgnen eller ligegyldigheden, for at bevare sproget som et muligt fællesskab eller for at bevare muligheden for at komme til orde i sproget som et individ med sin egen stemme.

Min samtalepartner ved den buldrende jernovn havde måttet lægge øre først til løgnen om proletariatets diktatur og siden til løgnen om det serbiske folks historiske ret. Løgne der begge fornægtede Kieslowskis lille sandhed om individernes anonyme skæbnefællesskab neden under alle historiske og etniske forskelle. Selv er jeg opvokset $i$ et mediesamfund, hvor individualismen har gjort individerne ensommere, end de behøver at være, og hvor identiteternes karneval har gjort dem usikre på, hvem de egentlig er. I hendes verden havde det ideologiske og mytologiske sprog fortiet, at ethvert fællesskab er et fælleskab af individer. I min har sprogets flerstemmige kværnen overdøvet den enkle indsigt, at ingen er mere enestående end enhver af de andre.

Uden at vide det provokerede hun mig til at fortsætte den tankerække, som jeg trægt og til tider endda modstræbende har fulgt $i$ nogle år, fra min indadvendte distraktion på hotelsengen i Edinburgh den 9. november 1989 til den spontane, overilede og kortvarige glæde, som jeg syv år senere delte med studenterne i Beograds gader.

En dag gik demonstrationen ad broen over Sava og gennem kvartererne på flodens modsatte bred. Novy Beograd var ikke anderledes end så mange andre forstæder i øst og vest med ringveje og højhuse af beton, blot endnu grimmere, men hverken mere eller mindre fortabt. Stedet havde det samme anonyme præg, der altid griber mig med den samme følelse af at være udenfor, ikke bare ude af byen, men også ude af historien, ude af cirkulation. Ishøj, Brooklyn, Malakoff, les boulevards extérieurs, det slumrende suburbia. Overalt er det den samme lokalbedøvede melankoli.

Højhusenes vinduer spejlede den lave sol som glinsende, orange mosaiksten midt $i$ vinterens falmede farver, himlens frosne lyseblå, den brune jord, de brune træer og de fugtskjoldede betonelementers gråskala. På nogle af altanerne stod beboerne og så os passere, de fleste af dem husmødre. Nogle vinkede, andre stod der bare, meget små og fjerne. Oppe fra altanerne måtte der være udsigt over Sava og Donau, de visne sivskove hvor floderne løber sammen under højen med fæstningsværker. Husmødrene måtte kunne se de langsomme flodpramme og det rolige, mudrede vand, der fortsætter hele vejen til Sortehavet, hvor Europa munder ud i siv og ingenting.

Mens jeg ser billedet for mig, kommer jeg igen til at tænke på, hvad Kieslowski sagde kort efter $\mathrm{Mu}$ rens Fald, få år før han døde. At folk stadig skal vente på bussen, og at de stadig vil dø af kræft. Jeg tænker på busserne i Beograd, raslende afsted med deres sorte skyer af dieseludstødning og klyngerne af trætte, udtryksløse ansigter bag de fedtede ruder. Og jeg tænker på kvinderne i aftensolen på Novy Beograds altaner, det almindelige liv som på skift er blevet forrådt og forladt af historien. Jeg tænker på løgnene om det og på de sandheder, der er at sige om dette liv, som sproget ofte fjerner sig fra $i$ en tuskhandel, hvor den lille historie byttes for en, der er stor. Heldigvis kan sproget også bruges til det modsatte. Det kan forsøge at nærme sig, idet ord- 
ene ,afsøger det mest meningsløse for betydning og det mest betydningsfulde for meningsløshed.“

Historien var ikke et posttog, der kørte gennem natten på vej til en bedre verden, og $i$ dag bliver brevene fløjet. Hvis der overhovedet er nogen, der skriver breve mere. Iøvrigt stod der nok ikke særlig meget om fremskridtets morgengry $i$ brevene, der blandede sig med hinanden i postsækkene. Breve til de rige og breve til de fattige, til butikken rundt om hjørnet og til pigen inde ved siden af. Der er ikke plads til den store historie $i$ et brev, kun til den lille. Det lille håb, den lille håbløshed. Men for den enkelte afsender og modtager er det også rigeligt, nok til en roman.

Hvert brev i postsækken er en hel verden for den, der sendte det, og for den, det blev sendt til. Alligevel kunne man have lyst til at bytte rundt på dem, omadressere hist og her, så modtagerne opdagede, hvor meget deres enestående historier ligner hinanden. Det bliver de jo ikke mindre enestående af. Det er selve vores adskilthed og ikke dens indhold, der gør os til nogen.

Sådan er det somme tider at læse en roman: som at fả brev fra en man ikke kender. Tilsammen udgør brevene i sækken den historie, der er at fortælle om verden lige nu. Hvis man stjal en postsæk, ville man endelig kunne komme i gang med Den Store Samtidsroman.

Og essayet? Det hører ikke hjemme i en konvolut, og det skrives heller ikke i brevets eller romanens fortrolige enrum, det personlige livs intime rum. Det bliver til i den gustne belysning i en af togets kupeer på vej gennem natten, med en sammenfoldet avis som skriveunderlag. Det bliver skrevet, mens de andre passagerer sover, læser eller ser tomt frem for sig. Nogle står af toget, andre stiger på, men selv om de ikke skal det samme sted hen, selv om de ikke kender hinanden eller taler sammen, så føler den skrivende alligevel, at han og hans medpassagerer deltager $i$ et kortvarigt fællesskab. Hvis der skete en ulykke, tænker han, ville de blive nødt til at røre ved hinanden.

Skriften bliver lidt sjusket på grund af togets rystelser, og somme tider bliver teksten også lidt usam- menhængende, fordi den skrivende ustandselig løfter blikket og ser ud gennem sit utydelige spejlbillede på lyset fra byerne, han kommer forbi. Han kan ikke se byernes lys uden også at få øje på sit eget blege fjæs i den dirrende rude, men han kan heller ikke betragte sig selv uden samtidig at se de spredte lys fra alt det, der passerer uden for ham selv.

Idet han fortsætter med at skrive, forestiller han sig måske, hvordan larmen fra toget får en kande til at klirre i et soveværelse et sted derude, og han smiler ved tanken om, at der alligevel er en skjult forbindelse mellem kandens umærkelige skælven og hans egen skælvende skrift. 